\title{
An Autobiographical Narrative Inquiry Into the Experiences of a Vietnamese Mother: Living Alongside Children in Transition to Canada
}

\author{
Hang Thi Thuy Tran \\ University of Alberta, Canada \\ Ho Chi Minh City University of Technology and Education, Vietnam
}

\begin{abstract}
Since my family came to Canada, family story nights have become our daily practice. Within such moments, I explore how I, as a mother, have been sustaining the Vietnamese language and traditions in my family and how, when transitioning to a new land, this has become the core of our familiar curriculum making (Huber, Murphy, \& Clandinin, 2011). As I share Vietnamese stories with my children, they reply to me in English. Also, they only have a distant understanding of Vietnamese culture and the intergenerational traditions of our great family back home. Acknowledging these transitional processes allows me to nurture their love and understanding of Vietnamese language, culture and traditions. As I inquire into my own experiences as a mother, I trace my ancestral heritage in my homeland, where, in Thúy's (2012) words, "a country is no longer a place but a lullaby." Meaningfully, the following questions have shaped my research puzzles: (a) What are possible ways to build our familial curriculum in integration with our homeland language, culture, and traditions; and (b) How could I as a mother sustain these three essential areas in my children's lives in Canada? I embrace autobiographical narrative inquiry as the methodology for my paper. Narrative inquiry draws attention to story as both the phenomenon under study and narrative as the methodology for the inquiry (Clandinin \& Connelly, 1994). I will be living, telling, retelling, and reliving (Clandinin, 2013) my storied experiences and my children's in our familial curriculum making through cooking, reading, and painting. By attending to my daughters' experiences, I inquire into their transitions differently, that is to understand their own transitions narratively (Clandinin, Steeves \& Caine, 2013). Significantly, this paper will bring understandings on Vietnamese newcomer mother's and children's familial curriculum making as a way to sustain the homeland's language, culture, and traditions and to support the children in their transition to a new country as well as inform related realities, knowledges, and approaches in education.
\end{abstract}

Keywords: experience; transition; curriculum making; language; culture; traditions

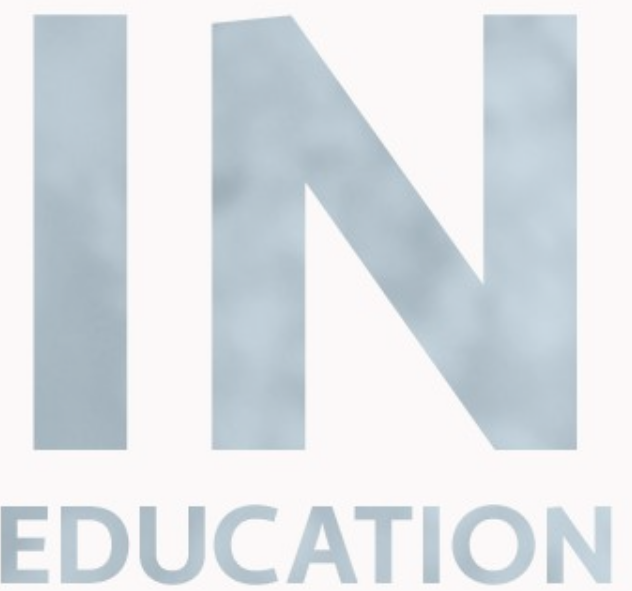




\author{
An Autobiographical Narrative Inquiry Into the Experiences of a Vietnamese Mother: \\ Living Alongside Children in Transition to Canada \\ A winter night \\ My children asked me in English: \\ "What's the meaning of your name?" \\ In Vietnamese, I replied: \\ "Nó là hi vong xanh, con ạ." \\ (It's a blue hope, my dears.) \\ Saying thanks to me, they asked: \\ "Why was so, Mommy?" \\ My mind travelled back \\ Five, ten years ago. \\ My Grandpa was old \\ And smart in his 90s. \\ I visited him \\ In our old home. \\ Hugging me, he said: \\ "Never forget, my dear \\ Your name is a blue hope. \\ Our family traditions \\ Always live with hope and pride. \\ Never give up, my dear \\ But step far and farthest \\ To make me proud \\ On earth and in heaven." \\ Now, look at the altar, \\ I miss him so much. \\ His Vietnamese words are here \\ To answer the children's question in English. \\ What if one day \\ Our traditions and language \\ Go far away \\ And are forgotten \\ What will happen in my children's lives? \\ In their life making \\ And in the lives of their children?
}

(Poetic fragment, written Winter 2018)

The poetic fragment above shows something of the practice of family story nights between me and my daughters, Joey and Sherry, as we have been in transition to Canada. We usually read aloud a bedtime story every weekday and live out family story night on the nights of the weekends. During family story nights, we read a book together - mostly in Vietnamese and sometimes in English - and then continue with long conversations about our great family: the current members, the ancestors, the traditions, fun stories told about happenings in our family, and so on. The family story night that becomes somewhat visible in the poem above is special to me because when I shared with my daughters the names of their grandparents and great 
grandparents, they asked me about the meaning of my name. More meaningfully, they raised the question in English language while my story was in Vietnamese language. Later, I explained my name's meaning with a small story in Vietnamese. Within that conversation, I used my mother tongue, Vietnamese, while my children used English, the language they have been learning since we came to Canada in summer 2015. I have been thinking so much about this experience as it has been repeated many times since that earlier family story night.

Over time, this experience led me to explore how I, as a mother, have been trying to sustain Vietnamese language for my children and with my children. Similarly, I am also aware that my children's understanding of the culture and traditions of our homeland and our great family is from a distance. Acknowledging these experiences in our transition to Canada encourages me to nurture my children's love and understanding for our mother tongue language and our familial and cultural traditions. As a newcomer Vietnamese mother living alongside my children in Canada, I do not want my children to no longer carry these treasures of my family and Vietnamese peoples. As I inquire into this experience and the everyday family practices that it shows, I trace our ancestor's heritages in my homeland "where a country is no longer a place but a lullaby" (Thúy, 2012, p. 140).

Since the beginning of our transitioning to Canada, because I see the significance of sustaining our language, traditions, and culture, I have carried two wonders: in part, I have wondered about how to sustain and extend our everyday familial practices inclusive of our homeland language, traditions, and culture and, too, I have wondered about my place, as a newcomer Vietnamese mother, in this process of sustaining these ways of knowing, being, and doing in our ongoing lives in Canada. Even though these wonders shaped my experiences during the first year of our life making in this new country, I could not figure out how to inquire into them. In part, I struggled because of a lack of available resources for Vietnamese newcomers like me to sustain our language, traditions, and culture. As well, as a mother, I had not experienced these tensions when we lived in Vietnam. That is, I remember saving almost all of my familial time with my first daughter for her homework at our small house in Saigon. For those days, we had tried our best to fulfill her schools' requirements of weekly tests, monthly tests, mid-term tests, end-of-term tests, and so many further exercises - each of which required 'beautiful handwriting practice'. Although Joey was just in Grade 1, too much homework kept us far from thinking about our language and our everyday familial, cultural, and traditional practices. More obviously, when we still lived in our home country, the sense of the meaning of place was not as strong as in those moments after we moved to Canada. Here, I am reminded of Basso's (1996) understanding of certain places as being imbued with a power to teach individuals in the key ways of wisdom. Reading Basso has given me more thoughts on my puzzles around our familial curriculum in Canada and the shaping influence of our everyday practices in the lives we are each making.

\section{Cornerstones of Living Alongside Children in Transition}

\section{Theory of Experience}

As I work on my autobiographical stories of living alongside my children, I find it essential to keep experience as the foreground of my paper. For Dewey (1938), education, experience, and life are inextricably intertwined. Generally sensing, when one asks what it means to study 
education, the answer is to study experience. Supporting Dewey, Clandinin and Connelly (1994) firmly assert:

The study of education is the study of life, for example, the study of epiphanies, rituals, metaphors, and everyday actions. One learns about education from thinking about life, and one learns about life from thinking about education. (p. 415)

Central in Dewey's (1938) theory of experience and education is the term situation, which is specified by two criteria-interaction and continuity. Interaction refers to the intersection of internal and existential conditions. Continuity accounts for the temporal positioning of every situation. Meaningfully, situations do not just happen; instead, they are historical and temporally directional according to the intentionality of the organism undergoing temporality. Thus, while we are talking about experience, we are talking temporally (Clandinin and Connelly, 1994, p. 416).

Additionally, while Dewey believed continuity is an essential part of all experience, he considered growth as the overarching goal of any experience, in terms of quality and types of experiences. Meaningfully, when unfolding the experience, each subsequent situation offers us "a novel perspective to look back on the experiences leading up to, and out of, an experience, making growth provisional and emergent rather than fixed and found (Downey and Clandinin, 2010, p. 384).

\section{Narrative Understanding of Transition}

Clandinin, Steeves, and Caine (2013) identify five qualities that shape their narrative understandings of transition. Firstly, transition is shifting over time and place; as when we think narratively about lives in the making, our past experiences become part of new stories to live by and their forward-looking stories. Secondly, with narrative inquiry, "we understand life making as a process; composed over time, in places, and in different relationships" (Clandinin, Steeves, \& Caine, 2013, p. 220). With this understanding, I see that people are always in continual movement, and their transitions speak to lives unfolding. Thirdly, these three authors see transitions as liminal spaces, based on Heilbrun's (1999) description of the "in-between" state created in transition. Heilbrun (1999) portrays this liminal space as "an indeterminate stage where we are neither here nor there" (p. 221). Fourthly, Clandinin et al. (2013) give me a way to see that improvisation is an integral part of transition. They pull out this point from their research with the early school leavers and from Bateson's (1994) suggestion that moment-to-moment embodied ways of improvisation give us a way to compose lives across transitions. Finally, thinking narratively paves a view that imagination and relationship are not separated from transitions. Within this awareness, the intertwinement between imagination and relationship helps us know more about our identity:

Relationships ignite imagination even as imagination ignites relationship. Relationships provide grounding from which to feel at ease, to make up other worlds, other ways of being. Relationships also provide opportunities to see things differently; broadening imagination of what could be when prescribed plotlines are no longer available. (Clandinin et al., 2013, p. 223) 
Above all, these five qualities of narrative understandings of transition powerfully prepare my knowledge before entering and exploring experiences of myself as a mother living alongside children in their transition to a new country.

\section{Familial Curriculum Making}

Huber, Murphy, and Clandinin's (2011) conceptualization of familial curriculum making has supported me to re-story the significance of my children's (Sherry and Joey) and my interactions with one another and others in our home and community places. As highlighted by Huber et al. (2011), while the concept of curriculum making has been used in education for many years, it is mostly applied to "teachers and others who attended to curriculum making in relation to the mandated or planned curriculum, that is, to curriculum documents or plans and to curriculum materials" (p. 9). As noted by Huber et al.'s (2011), the narrative understanding of curriculum opened potential for understanding curriculum not only as a course of study but also a course of life (making): "We understood curriculum making as a life-making process (Clandinin \& Connelly, 1992) in which identity making, that is, stories to live by, was central" (p. 221).

As Huber et al. (2011) attended closely to the worlds of children in their research on experiences of children, families, and teachers in an era of growing standardization and achievement testing, they saw another place of curriculum making, different from school curriculum making, which they conceptualized as "familial curriculum making." In their perspective, familial curriculum making is seen,

As an account of parents'/families' and children's lives together in homes and communities where the parents and families are an integral part of the curricular process in which families, children/learners, subject matter, and home and community milieu are in dynamic interaction. (pp. 7-8)

Significantly, Huber et al. (2011) have shaped my knowledge of familial curriculum making around five aspects. Firstly, they view familial curriculum making as intergenerational, in which I see the potential of the family's language, traditions, and culture to be lived, told, retold, and relived across different generations, interconnectedly and interdependently. The second aspect of familial curriculum is its responsiveness, which comes out of the daily interactions happening among family members, such as the interactions between children and parents, brothers and sisters, and so on. What is beautiful here is that familial curriculum making could include a wide range of activities, for example, "baking, singing, making puzzles, learning the alphabet, cleaning, name printing, drawing, telling stories, making plays, watching TV or a movie, taking walks, going for bike rides, picking flowers, and resting" (Huber, Murphy, \& Clandinin, 2011, p. 41). A third aspect is that familial curriculum making needs to start from the child, which means that the child's identity making is the center of this curriculum. I learned from this aspect that the child, as do we all, carries all of her or his experiences in her or his body; thus, understandings of knowledge as embodied are central here. Additionally, a fourth aspect I am drawn toward is that familial curriculum making has multiple co-composers. These diverse co-composers are people in the child's family and in her or his surroundings, and they could also be things in the home and community contexts of the child such as music, books, animals, and the natural world. The last aspect is that familial curriculum making focuses on life in the long term. As the temporal aspect of familial curriculum making always looks forward to 
the future, it helps create the ground and strength for the child to compose her or his future with her or his best capacity.

As I have lingered with these understandings of familial curriculum making, I realize that they offer another way for me to attend to the wholeness and complexity of lives in transition. From my earlier stories I realize that in Sherry and Joey's transition to school, school curriculum making has been privileged. In my thinking narratively with these experiences, I see the urgency of attending to familial as well as school curriculum making. I wonder if this multi-perspectival attending could better support my children and myself as a mother, all of whom are new to and in transition to Canada, where we are composing our lives.

\section{Intergenerational Narrative Reverberations}

As I think about who I am and who I am becoming as well as how my experiences have brought me to living alongside my children in our transition to Canada, I am very much reminded of my extended family's stories, and the stories I lived before transitioning to this country. Young's (2005) research, Pimatisiwin: Walking in a good way. A narrative inquiry into language as identity, shows me the importance of intergenerational narrative reverberations, which relate to the loss of language, traditional and cultural knowledge, spiritual, and relational practices, particularly family relationships. Being a student of Residential School and assimilated to speak English only, Young (2005) shared that she felt sad that she did not know her language, Anishinaabe. I was very drawn in by Young's stories of the loss of her language as I deeply resonated with her sense that language and identity are connected and that losing our language is like losing a part of our selves. I do not expect my children to lose their ability to speak our first language. If they do, they will feel the loss of their Vietnamese identity.

Young (2005) has also brought to me the reverberations of traditional and cultural knowledge within intergenerational stories. As I think of my experiences alongside the experiences that Young (2005) inquired into in her life making, I wonder what I as an offspring of Vietnamese ancestry and a child of my great family wish for my children in relation with sustaining our language, traditions and culture.

\section{Methodology: Narrative Inquiry}

My journey into the understanding of narrative inquiry is profoundly connected to my transition to Canada. I still remember the first time I came to the Research Issues table at the Center for Research for Teacher Education and Development, University of Alberta. It was at this beautiful table with amazing people, I started to learn about narrative inquiry by bringing my stories to share and by hearing the stories of others shared. My very first imagining about this methodology is that people do not only tell stories but also think over the stories again and again when revisiting them. Later, I was very excited to discover the conceptualization of narrative inquiry from Clandinin and Connelly (2000):

Narrative inquiry is a way of understanding experience. It is collaboration between researcher and participants, over time, in a place or series of places, and in social interaction with milieus. As inquires enter this matrix in the midst and progressive in the same spirit, concluding the inquiry still in the midst of living and telling, reliving and retelling, the stories of the experiences that made up people's lives, both individual and social. Simply stated, narrative inquiry is stories lived and told. (p. 20) 
Here I get to learn that narrative inquiry is the study of experience contextually and temporally. Clandinin and Connelly's (2000) conceptualization of narrative inquiry experience is central as is the understanding that the closest we can come to experience is through the stories people live and tell.

Being different from other methodologies, a narrative inquiry is the result of collaborative composition of stories between researcher and participants. Together, they co-compose, tell, and retell stories in order to "honour shared experiences through relationships and offer the ability to grow through stories" (Lessard, 2010). Additionally, narrative inquiry is conceptualized in a three-dimensional space, which includes temporality, sociality, and place. The first dimension is temporality or time, covering the past, present, and future. These three aspects of our "lived time" are not linear but blended and supportive to each other. The second dimension is sociality, or the personal and social relationships of participants. According to Clandinin (2013), "social conditions refer to the milieu, the conditions under which people's experiences and events are unfolding" (p. 40). In particular, "the conditions are understood in terms of cultural, social, institutional, familial, and linguistic narratives" (p. 40). At this important point, I consider how plentiful, diversified and complex the participants' relationships are. The third dimension relates to place, which is defined by Connelly and Clandinin (2006) as "the specific concrete, physical, and topological boundaries of place or sequences of places where the inquiry and events take place" (p. 480). Lessard (2014) states, "Reflecting on the important of place within experience and the multiple meanings within its definition helps me inquire into the stories that are shared on various landscapes but also the places that we have travelled to as we share our stories" (p. 46).

In sum, narrative inquiry, with its three-dimensional space of temporality, sociality, and place, is my fundamental research methodology because it could help me revisit and understand my experiences as well as my children's experiences. According to Yeom (1996), when we tell and retell our stories, we respond "to the whole and reflect on the meaning of our experiences to understand ourselves and the world around us" (p. 35). Eventually, by "living, telling, retelling, and reliving" (Clandinin, 2013) the stories of our transition to Canada, I may understand my experiences as a mother living alongside children. More meaningfully, the understandings of my experiences have paved the way for me to attend my daughters' experiences, understand and support them as newcomer children to Canada and to Canadian schools.

\section{Telling Stories of a Mother Living Alongside Children in Transition to a Country}

It was not until I read Places of Curriculum Making: Children's Lives in Motion, in which Huber et al. (2011) reconceptualize curriculum making that I began to know familial curriculum making as the ways that parents, families, community members, and children live with one another in their homes and communities. This understanding supported me to begin to awaken to seeing that what I have been doing with my children at home is curriculum making. Later, as I began to name this process familial curriculum making, I deeply sensed its importance in our daily life making.

Gradually becoming imbued with the significance of familial curriculum making, I have carefully begun to shape our family story nights as a curriculum that starts from, and with, my children; that I, as a mother, and my children are co-composers in and of this week-end as well as other daily practices; and that our familial curriculum making stretches backward in time and 
across place to earlier generations of our great family. Because my children love Vietnamese traditional foods, books, and arts I decided that these three aspects could be the fertile land for growing their knowledge of our mother tongue language, traditions, and culture.

\section{Cooking as an Intergeneration-Nested Tradition}

My daughters are interested in cooking even though they are still in the early grades of elementary school. I now understand that the love of cooking, especially cooking our Vietnamese traditional foods, is an intergenerational reverberation in our great family. In our hundreds-year-old kitchen located in my birthplace village, teaching and learning how to cook has been a curriculum passed through generations of our female ancestors. My greatgrandmother taught my grandmother, my grandmother taught my mother, and my mother taught me the same lessons of making traditional dishes of Vietnamese, or our village, and of our family. I now see these significant and unique teachings of different cuisine as spiritual treasures that I brought to our new kitchen in Canada, where I continue teaching my daughters how to cook. For every Lunar New Year celebration, we always make and cook Chung cakes, a Vietnamese traditional heritage food. Significantly, this cake symbolizes the earth and conveys the wishes for a new year full of health and prosperity.

The preparation for this cake requires time, patience, and skillful techniques but the outcomes are wonderful. As usual, I soak the glutinous rice and green bean in cool water, mix pork with some spices and let them rest for a night. The following morning, we prepare the banana leaves and cords to get ready for wrapping the cakes. My children really enjoy the moments when we wrap the cakes together. Putting the banana leaves inside the wooden frames, we add rice for the first layer, steamed green bean for the second layer, pork for the third layer but just in centre area, then green bean again for the fourth layer, and finally rice for the last layer. After that we wrap and tie the cake with the cord so that it looks nice in the square shape. What makes the wrapping time more fun and meaningful is that I, as a mother, do not only teach my daughters the ways to make Chung cakes but I also tell them stories about the meanings of the cakes and of family stories that have happened in our great family over time and place: Stories of our ancestors beginning life in the village four hundred years ago, stories of their great-great-grandparents building the church, stories of great-grandparents working hard to raise their grandparents during the periods of losing crops, stories of grandparents overcoming poverty to fulfill the dreams of overseas study are among the important stories that we tell and retell yearly in preparation of Chưng cake. My children are always keen on these stories and raise many questions for more knowing and understanding. Interestingly, my parents in Vietnam also make the Chung cakes at the same time, so we often have conversations via Skype or Face book Messenger. Beautifully, three or four generations enjoy sharing stories, fun, and family love during the moments of wrapping Chung cakes, across the places of Vietnam and Canada, a distance of more than ten thousand miles. As I finish the 11-hour boiling step, I choose the best cakes to put on the altar as a gift to our ancestors. Looking at the Chung cakes on the altar, I promise to my ancestors that as a mother, I will sustain this tradition for my children as it has become a sacred part of our familial curriculum making. 

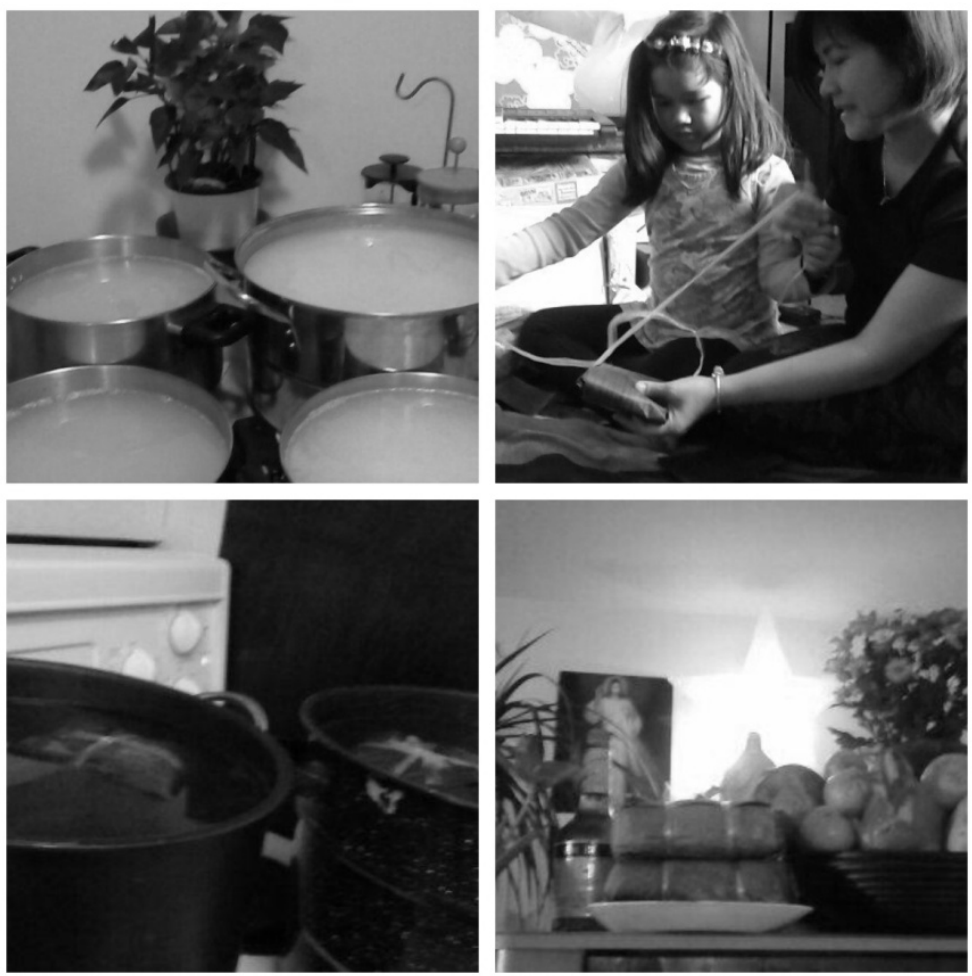

Figure1. Photo collage of making Chung cakes, taken Lunar New Year 2018

Because cooking has been a thousand-years tradition of our people, it plays an essential role in Vietnamese family life. Being inspired by this lengthy tradition, I wrote a poetic fragment denoting our kitchen, where different female generations of my great family as well as other Vietnamese families have been sharing knowledge and love to each other.

My Mom was young

My Grandma taught her cooking

Those Vietnamese traditional foods

Chung cake, Tét cake

And lotus seed sweet soup

Our little kitchen

Brings all flavours of the countryside

I turned to six

My Mom taught me cooking

In the same kitchen

Same Chung cake, Tét cake

The lotus seeds

And other cultural dishes

All raised me up

My daughter is seven

I teach her cooking

Same Chung cake, Tét cake

Same lotus seeds

In our new kitchen 
In a new country

Those traditional foods

Since my Mom and Grandma

Are now with us

In our conversations

In our stories

Traditions

And wisdoms

Offamily

(Poetic fragment, written Winter 2016)

As I lingered with images and memories of our kitchen in the past and in the present alongside my wonders of connections between being in transition, intergenerational narrative reverberations, and the stories we live by, with, and in (Okri, 1997; Clandinin, 2013), as we make our lives, I thought about the intergenerational knowledge and education shaping my great family for a long time. I am humble to see how these stories we live by, with, and in include our traditional and cultural knowledge as well as the spiritual and relational practices that we have long inherited from our ancestors. As I am coming to see the kitchen as not only a space at a certain time, I sense these practices of cooking also shape my children's experiences as they are in transition to Canada; in this way the kitchen "travels" back and forth in me and other generations of our great family.

\section{Reading Books as a Family's Everyday Practice}

Another familial curriculum that Joey, Sherry, and I make together is reading books and telling stories. As in the poem of family story time that I shared earlier, reading books together is an everyday practice in our little family in Canada. For the weekdays, my daughters choose to read their favourite English books for bed time after they practice their spelling words and do the Mathletics ${ }^{\circledR}$ online. For the weekends, we have more time as the children do not have school the following mornings. I have filled up our family time after dinner with many books in Vietnamese language, some that I brought along as our journey to Canada began, some my mother had my friends carry from Vietnam when they visited us, some I borrow from Edmonton Public Library, and some are used books I buy online.

Some family story times I spend time with my children reading popular Vietnamese tales such as Truyện Kiều (The Tale of Kieu) written by Nguyễn Du (1820), who is a world renowned poet, whose work has been recognized by UNESCO. Sometimes we read by heart and even sing Nghe Tinh folk songs, an intangible cultural world heritage, and we read many more Vietnamese children's books. We also read The Lotus Seed (Garland, 1993), an English children's book about $B \grave{a}$ (Vietnamese word for Grandma), a special Vietnamese woman with a strong love for the lotus seed that she carried to America as a valuable gift of her Vietnamese history, the precious characteristics of Vietnamese women, and a strong spirit of Vietnamese traditions. I mostly read but increasingly Joey reads with me. Sherry knows very few Vietnamese words, so she remains quiet and listens to us. After a story, or part of a story, many conversations unfold thanks to questions from my children and little pieces of stories for further clarification or explanation from me as their mother. In The Tale of Kieu, for instance, it is not only about the stories of a Vietnamese girl, who is beautiful both in appearance and in personalities, but also 
about the ways people choose to sacrifice for country and the good relationship of sisterhood. As well, Nghe Tinh folk songs cover many meaningful lessons on love of nature, homeland, family, and community.

Spending time on reading books with my children, I have been awakened with two different thoughts. On one side, I have found that as we have gradually read these books, more love of our mother tongue language has grown in Sherry and Joey. Also, seeds have been planted for their growing understandings of our traditions and culture that shape our experiences of composing lives in transition. On the other side, I have been reminded of those upset stories of my little daughters in their first months at Canadian schools. My first daughter kept crying all the time after school because she could not understand her teacher's English language, nor could her teacher understand her Vietnamese. Meanwhile, my second daughter also cried as her teacher negatively criticized her reading level in the "Learning Celebration Night," in which the teacher said that my daughter's reading was at the lowest level among her peers, and that she should have been at level E instead of level C. Thinking with these two stories and also other tearful ones of my children, I have intentionally chosen both Vietnamese and English books for them. I wish not only to keep their mother tongue language but also to help them improve English language literacy.

\section{Painting as Colorful Learning and Sharing Moments}

In addition to cooking and reading, together we also co-compose a familial curriculum around and through painting. Across the generations, I have seen the love of painting spread from my grandfather's cousin, who is a countryside artist, to me, and now to my daughters. We all show deep interest in the combination of colors and shapes. With painting, my daughters can spend tons of their free time making canvases of flowers, young children, family, and natural landscapes. On snowy Sundays, we stay at home and paint the same topic. As I now think with these images and memories of these experiences alongside Joey and Sherry, I find it interesting that we tried to simulate some famous masterpieces and then compare to our three masterpieces'. Because painting requires a lot of time and effort, we sing Vietnamese songs or talk together in our home language during the painting time, which is then followed by stories about beautiful landscapes and family members in my hometown. Again, painting has contributed to shaping my children's knowledge of our great family and homeland.

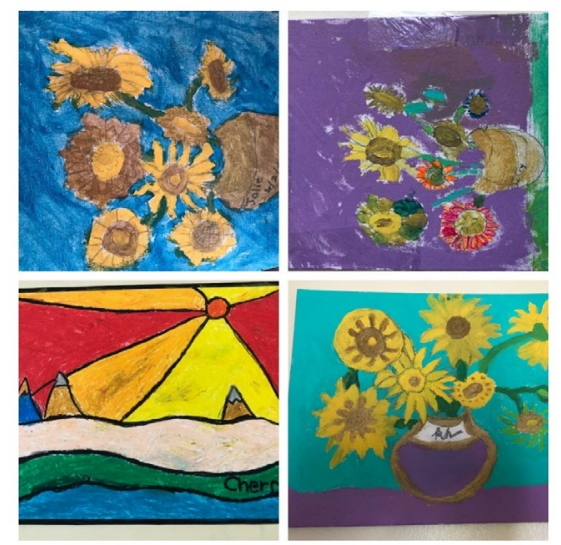

Figure2. Canvas paintings by Joey, Sherry, and me, done in 2017 


\section{Retelling Stories: Forward-Looking Thoughts and Imaginings}

Retelling the stories of myself as a mother living alongside children in transition to Canada has opened more space for me to understand my experiences. When revisiting my stories, I relive my experiences again and again. Sensing all of these, I am very much reminded of the extraordinary potential of living, telling, retelling, and reliving stories of experiences from Huber, Caine, Huber, and Steeves (2013):

Throughout the ages and across cultures story continues to express the fundamental nature of humanity. Stories are not to be treated lightly as they both carry, and inspire, significant obligations and responsibilities: stories must be cared for as they are at the heart of how we make meaning of our experiences of the world. Indeed, "storytelling is about survival." (p. 214)

Here, I truly learn that stories are not simply the stories for telling and listening as I used to think before coming to comprehend narrative inquiry. Meaningfully, when coming to me with the cycle of "living, telling, retelling, reliving" (Clandinin, 2013), stories have become a teacher of mine, which can help me look backward to how I have lived in the past. This "teacher" also helps me look forward to how I will live in future. In addition, I could "see" my inwardmyself - and from this, I would be able to imagine my outward - my relationship with the others, with respect to the experiences I have lived. With me, storytelling is an honest and valuable way of making sense of my lived experiences; indeed, it is about my survival, in living alongside my children when we transition to a new and strange country.

As I have been living alongside and co-composing our familial curriculum with my children, I have seen the power of cooking, reading, and painting in supporting my hope to sustain our mother tongue language, culture, and traditions for, and with, my children. It was not until I lived alongside my daughters in our transition to Canada, that I could recognize the extraordinary potential of our everyday practices, which I used to believe were simple and normal things.

Furthermore, as a "novice researcher," I realize that I always attend my stories and alsomy children's stories, in relational ways. As shared in the methodology section, I employ narrative inquiry as the methodological anchor for my journey in understanding my experiences of living alongside my children in their transition to Canada. As I remember my children's and my lived and told stories, I revisit the experiences within the three-dimensional space of narrative inquiry: temporality, sociality, and place. Thinking with temporality of my autobiographies, I strongly sense that what happened in the past will shape who we are at present and shape who we are becoming in the future. When I attend my daughters' stories, I move backward and forward to understand their experiences. This movement of my thought shows me many special things related to our transition. Before the transition to this new land, we had lived together in a small house in Saigon-Vietnam, where there was very little time spent on our familial curriculum. I sense the reasons lie at two points: one point is from that our family time was for the children's heavy homework before the bed time; the other is from that we had not especially recognized the significant meaning of our home language, culture, and traditions when living in our home country. It is the presence of being in transition awakening in me the meaning of co-composing familial curriculum with my children as a way to help sustain their language, culture, and traditions. Fast-forwarding my thought to the future, I wonder what would happen if 
the teachers and schools of my children see the hidden stories after their crying experiences in class. I also imagine the magic of the schools and teachers travelling back and forth among the past, present, and future in shaping their understandings toward my kids as newcomer children. It would be wonderful if they chronologically locate the cultural and traditional aspects in shaping their knowledge of newcomer children, from which they could help ease the tension, tear, and loneliness and support their development.

Thinking with sociality, I wonder a lot on the relationship between me as a mother and my children in our familial curriculum, in which we mutually negotiate and co-compose, teach and learn together, to build up knowledge and understanding on our Vietnamese language, culture, and traditions. It is obvious to see from mine and my children's experiences that together we could build up beautiful and beneficial activities in our family practice, daily and weekly. At this point, I can see that composing lives in transition could convey both challenge and beauty toward the sociality of my children. The challenge comes to my little angels as they are newcomer students having suffered lots of tear and loneliness due to the miscommunication in English language with their teachers and classmates. The beauty comes from their closer relationship with mother thanks to more time spent on family activities, sharing conversation, and understanding each other. Further, our experiences of being in transition have raised the impact on our social relationship. Back home, we had many social interactions with relatives, friends, and communities. However, our time marked by transition to Canada gives us fewer relationships outside our home. On one hand, fewer interactions with our new society has made us feel isolated from community; on the other hand, we save time and love for family members and thus much strengthen our motherhood.

Regarding the place dimension, I think a lot on the situations of my children's learning happening inside and outside the school contexts. From my own experience, it resonates with me that we are able to build our home curriculum in our own ways. But what about the possibility for integrating such curriculum to the school curriculum? Can the school and teachers engage the children's homeland culture and family traditions to the in-school lessons and activities? Also, where do I find the voice and agency for my children in their rights of choosing the most appropriate learning styles or the one they were familiar with before moving to this new country? As I ponder these questions, I see the meaning of my children's stories in which they have somehow carried with them the spirit of their homeland. As a mother, I value their question on the meaning of my name thanks to their love and care for me and the intergenerational wisdom accompanying them to this land. As an educational researcher, I feel humble with my children's inherited identity - the love of traditional cooking, reading, and painting - with which they grow up when living in the new land of more than twelve thousand miles distance from their birthplace.

\section{Conclusion}

As I move beyond the above stories in my autobiography, I have been awakened to the possibilities of unpacking the experiences of my daughters as newcomer children and my experiences as a mother living alongside them. In particular, I see the attentive necessity of recognizing ways of being, knowing, and remembering in our lived, told, retold, and relived experiences of composing lives in transition. My forward-looking thoughts and imaginings shape four meaningful points. The first one is shifting from merely focusing on dominant stories of children learning at school, to including related ways of learning at home, in which parents and 
children collaborate in their curriculum making. It is obvious that understanding how children learn at home will absolutely benefit the schools' and teachers' ways of supporting newcomer children. They could, for example, design the specific learning activities based on these children' favourite learning styles or scaffold the children's development based on their identity. Doing so will help ease their tensions when first coming to new schools in a new country. The second point is that mothers could build familial curriculum for their children through a wide range of learning activities such as family intergenerational story-telling, bed time reading, cooking, painting, singing, and so on. The third point is to acknowledge the powerful role of intimate relationships: children learn best within the support from parents, grandparents, and siblings. These intimate relationships are a truly valuable support as parents are the ones who know their children's learning preferences at best. Within this paper, I emphasize the roles of mothers but not the fathers because in Vietnamese culture, men usually work outside the home, in society for earning money to raise the whole family, whereas, women are responsible for "making home" educating the children and taking care of the housework. Last but not least, understanding on children's experiences of learning at home could not only help maximize their learning opportunities but also help sustain the value of their home language, culture, and traditions.

Indeed, I imagine a place where teachers and parents can sit together for more integrating of ideas on classroom lessons, homework tasks, extracurricular activities, and other aspects related to the children's mother tongues, cultures, and traditions. Practically, this imagined place will help teachers and schools show their appreciation to the newcomer children's identity in their life making. It also creates a possible assistance for teachers to know more deeply who the newcomer children are and whether they have disabilities in English language learning, adapting to the new culture, and many other facets. Teachers' knowledge on these aspects will give them ways to scaffold the children's knowledge development appropriately and effectively. Eventually, co-creating curriculum between families and schools could facilitate the diversity, equity and inclusion in education for every single newcomer student.

As I inquire into my experiences as a mother living alongside children who are composing lives in transition to Canada, I gradually make the invisible experiences of my children as newcomers at schools become visible. By traveling into their "worlds" inside and outside school landscapes, I could attend to their experiences more deeply than ever before. With the modest knowledge of a newcomer mother, I am not confident to be the pedagogical agent of my children, but I have tried my best with all my love, to make the unfamiliar everyday practices become familiar and beneficial in our home curriculum. Learning the relational ethics of narrative inquiry has given me the bravery to share stories of my children and myself. I hope that sharing experiences of a newcomer mother like me could bridge the gap in understanding between the two worlds of children's curriculum making: familial and school. I feel profound gratitude to share the wisdom of what a mother knows of her children's lives to help shape culturally informed educational policies, programs, and practices in welcoming and supporting newcomer children. These perspectives, therefore, meaningfully counter what has become dominant story, and suggest alternatives that represent different realities, knowledges, and approaches in education. 


\section{References}

Basso, K. H. (1996). Wisdom sits in places: Landscape and language among the Western Apache. Albuquerque, NM: University of New Mexico Press.

Bateson, M. C. (1994). Peripheral visions: Learning along the way. New York, NY: HarperCollins.

Clandinin, D. J. (2013). Engaging in narrative inquiry. Walnut Creek, CA: Left Coast Press.

Clandinin, D. J., \& Connelly, F. M. (1994). Personal experience methods. In N. K. Denzin \& Y. S. Lincoln (Eds.), Handbook of qualitative research (pp. 413-427). Thousand Oaks, CA: Sage Publications, Inc.

Clandinin, D. J., \& Connelly, F. M. (2000). Narrative inquiry: Experience and story in Qualitative inquiry. San Francisco: Jossey Bass.

Clandinin, D. J., Steeves, P., \& Caine, V. (Eds.). (2013). Composing lives in transition: A narrative inquiry into the experiences of early school leavers. Bingley, UK: Emerald.

Connelly, F. M., \& Clandinin, D. J. (2000). Narrative inquiry: Experience and story in qualitative research. San Francisco, CA: Jossey-Bass.

Dewey, J. (1938). Experience and education. New York, NY: Macmillan.

Downey, C. A., \& Clandinin, D. J. (2010). Narrative inquiry as reflective practice: Tensions and possibilities. In N. Lyons (Ed.), Handbook of reflection and reflective inquiry: Mapping a way of knowing for professional reflective inquiry (pp. 383-397). Berlin, GE: Springer.

Garland, S. (1993). The lotus seed. Orlando, FL: Harcourt.

Heilbrun, C. G. (1999). Contemporary memoirs: Or, who cares who did what to whom? The American Scholar, 68(3), 35-42.

Huber, J., Caine, V., Huber, M., \& Steeves, P. (2013). Narrative inquiry as pedagogy in education: The extraordinary potential of living, telling, retelling, and reliving stories of experience. Review of Research in Education, 37(1), 212-242.

Huber, J., Murphy, M. S., \& Clandinin, D. J. (2011). Places of curriculum making: Narrative inquiries into children's lives in motion. London, UK: Emerald.

Lessard, S. (2010). "Two-stones" stories. Unpublished Master's thesis. University of Alberta, Canada.

Lessard, S. (2014). "Red Worn Runners" A narrative inquiry into the stories of Aboriginal youth and families in an urban school setting. Unpublished doctoral dissertation. University of Alberta, Canada.

Nguyễn, D. (1820). Truyện Kiều/ The tale of Kieu. New Haven, CT: Yale University Press.

Okri, B. (1997). A way of being free. London, UK: Phoenix House.

Thúy, K. (2012). Ru. Toronto, ON: Random House Canada. 
Yeom, J. (1996). From the voices of children: Transition stories from kindergarten to grade one. [microform]. University of Alberta.

Young, M. I. (2005). Pimatisiwin: Walking in a good way. A narrative inquiry into language as identity. Winnipeg, MB: Pemmican. 